\title{
ANNA TARWACKA*
}

Uniwersytet Kardynala Stefana Wyszyńskiego

\section{EI FORAS, MULIER, CZYLI ROZWÓD W KOMEDIACH PLAUTA}

Źródła prawa rzymskiego dla okresu republiki, czyli od roku 509 p.n.e., kiedy to - według legendy - Marcus Iunius Brutus podburzył Rzymian do wygnania króla Tarkwiniusza Pysznego, do roku 31 p.n.e., gdy Oktawian - po zwycięstwie nad Antoniuszem w bitwie morskiej pod Akcjum - stał się faktycznym jedynowładcą Rzymu', dotarly do nas własciwie jedynie w przekazach późniejszych jurystów. Podstawą współczesnej wiedzy na ich temat jest kodyfikacja justyniańska, której twórcy bardzo swobodnie traktowali teksty, jakimi dysponowali i niejednokrotnie dokonywali w nich interpolacji. W tych okolicznościach prawdziwym skarbem okazało się odkrycie palimpsestu Instytucji Gaiusa, jurysty z II wieku n.e., który - poza współczesnymi sobie instytucjami prawa - omawiał również archaiczne rozwiązania prawne. Mimo tego, źródła, jakimi dysponują romaniści, są wysoce niekompletne.

Rozwiązaniem tego problemu niejednokrotnie już okazywała się literatura piękna. Jej wartość docenić pozwalają chociażby rekon-

\footnotetext{
* Autorka jest Stypendystą Fundacji na rzecz Nauki Polskiej.

' Za początek pryncypatu z prawnego punktu widzenia uważa się rok 27 p.n.e., kiedy Oktawian przyjąl tytul princepsa. Mialo to związek ze sprawowaniem przez niego cenzury, z którą lączyło się przyznanie tytułu pierwszego pośród senatorów, czyli princeps senatus.
} 
strucje Ustawy XII Tablic: treść wielu przepisów udało się ustalić na podstawie dzieł nieprawniczych, takich jak pisma Cycerona, Aulusa Gelliusa, Festusa czy Liwiusza².

Skąd jednak pewność, że dzieła tych autorów są wiarygodne jako przekazy norm prawnych? Otóż, prawo było znane Rzymianom jak mało któremu narodowi. To właśnie ono stanowiło płaszczyznę porozumienia między obywatelami, pewien powszechnie zrozumiały kod. Oto jak wygląda definicja państwa włożona przez Cycerona w usta Scypiona Afrykańskiego: Est igitur, inquit Africanus, res publica res populi, populus autem non omnis hominum coetus quoquo modo congregatus, sed coetus multitudinis iuris consensu et utilitatis communione sociatus ${ }^{3}$. Naród zatem to zbiorowość połączona wspólną świadomością prawną. O ile współczesne narody nie mogą się raczej poszczycić podobną znajomością prawa, Rzymianie byli w tej dziedzinie ekspertami. Dzisiaj autorzy książek czy scenariuszy filmowych prowadzą z czytelnikiem lub widzem swoistą grę intelektualną posługując się powszechnie znanymi cytatami literackimi, a w kulturze masowej nawet sloganami reklamowymi. Dzieła pisarzy rzymskich pełne są takich „oczek” puszczanych do czytelnika, a opartych na instytucjach prawnych. Gra polega na odnalezieniu aluzji. Aby zatem w pełni zrozumieć tekst, trzeba znać prawo. $\mathrm{Z}$ drugiej strony, takie odniesienia do prawa często pozwalają na pełniejsze zrozumienie funkcjonowania danej instytucji. Nie są to zapisy ustawodawcy, ale głos społeczeństwa, dzięki któremu poznać można odbiór poszczególnych norm prawnych, zakres ich faktycznego zastosowania, wykonalność, faktyczny zasięg zastosowania instytucji.

Dialog pisarza z przeciętnym Rzymianinem nie mógł raczej odbywać się za pośrednictwem słowa pisanego. Obywatele słuchali mów wygłaszanych na forum, chodzili do teatru. Dlatego też, aby dowiedzieć się czegoś na temat niższych klas społecznych, odwołać

' Por. M. i J. ZABŁoccY, Ustawa XII tablic. Tekst - tlumaczenie - objaśnienia', Warszawa 2003, s. 6-8.

${ }^{3}$ Cic., de rep. $1,25,39$. 
się należy do zachowanych tekstów komedii rzymskich. W całości zachowały się jedynie sztuki należące do gatunku palliaty, czyli wzorowane na greckiej komedii średniej oraz - przede wszystkim nowej.

Najsłynniejszym autorem palliaty był Titus Maccius Plautus urodzony około roku 250 p.n.e., który tworzył mniej więcej w latach 210-184 p.n.e. Informacje na temat jego życia znaleźć można w Noctes Atticae Aulusa Gelliusa ${ }^{\star}$. Antykwarysta podaje kilka szczegółów dotyczących młodości komediopisarza: początkowo pochodzący z Umbrii Plautus miał pracować w teatrze in operis artificum scaenicorum. Zarobione w ten sposób pieniądze stracił w handlu i z pustymi rękoma wrócił do Rzymu, gdzie zatrudnił się w piekarni i tam napisal swoje pierwsze komedie: Saturio, Addictus i jeszcze jedną, której tytułu Gellius nie znał.

W starożytności znano 130 komedii przypisywanych Plautowi. $\mathrm{Z}$ tej listy Varro wyselekcjonował 21, tzw. fabulae Varronianae, które uznał za bezsprzecznie autentyczne. Do naszych czasów dotrwalo właśnie 21 sztuk, a także liczne fragmenty ${ }^{5}$.

Jako że palliata wzorowana była w dużej mierze na sztukach greckich, o czym zwykle możemy przeczytać w prologu komedii, zachodzi obawa, że także realia czy też normy prawne są greckie, a nie rzymskie, co uniemożliwiłoby badania nad prawem rzymskim. Przede wszystkim pamiętać trzeba, że swoje komedie Plaut pisał dla publiczności`. Troska o to, aby widzowie bawili się jak najlepiej, była jego najważniejszym zadaniem. Czego zatem oczekiwali Rzy-

+ Gell. 3,3.

"Varro napisal niezachowane dzieło De comoediis Plautinis. Por. M. CYTOWSKA. L. RYCHLEWSKA, Literatura rzymska. Okres archaiczny, Warszawa 1996, s. 47.

"R.C. BEACHMAN, The Roman Theatre and Its Audience, London 1990), s. 29: Plautus, along with other ambitious Roman playwrights, had to perform a balancing act, presenting plays, part of whose appeal must have been that they satisfied the new fashion for things Greek, while at the same time taking care not to make eccesive demands on the sophistication of their audience, or neglect altogether its established taste for traditional fare. 
mianie przychodzący wówczas do teatru? Głównie zabawy. O tym, że latwo było ich znudzić, świadczą chociażby incydenty, jakich na własnej skórze doznał Terencjusz, kiedy to publiczność uciekała $\mathrm{z}$ jego przeintelektualizowanych komedii na pokazy linoskoczków. Plautowi nie zdarzało się to nigdy. Jego vis comica jest wręcz przysłowiowa?.

Każdy współczesny czytelnik zwraca uwagę na dość wyraźnie rzucającą się w oczy niemoralność Plautowych komedii. Biorąc jednak pod uwagę surowość obyczajów w Rzymie III/II w p.n.e., trudno przypuścić, aby widzowie latwo mogli tolerować taką satyrę $z$ siebie samych. Należy przypuścić raczej, że traktowali to jako żarty z Greków, których mieli przecież za uosobienie wszelkiego bezeceństwa. Nawet jeśli w ich społeczności zdarzały się podobne ekscesy, były one ściśle ukrywane i pozostawały wewnątrz familii.

Komedie Plauta rozgrywają się w greckich miastach, a i pewne ich szczegóły odwołują się właśnie do tamtego świata. Pieniądze, jakimi posługują się bohaterowie, to najczęściej miny. Pamiętajmy jednak, że publiczność Plauta nie należała do najlepiej wykształconych warstw spolecznych. O Grecji nie wiedziała zbyt wiele, w pamięci mała przede wszystkim garść stereotypów, jakimi posługiwano się na co dzień. Aby stworzyć odpowiedni klimat, wystarczało zatem tych kilka powierzchownych szczegółów. Przesada byłaby tu zresztą niewskazana - nie warto przecież ryzykować, że większość widzów nie zrozumie sytuacji scenicznej przesyconej obcymi wzorcami życia. Dlatego też myślę, że z dużym prawdopodobieństwem można przyjąć tezę o rzymskości świata Plautowego. Komedie ośmieszają Greków, ale ówczesny widz z łatwością doszukiwał się znajomego klimatu własnego życia i sytuacji społeczno-prawnej.

Należy jednak zachować daleko posuniętą ostrożność, jeśli chodzi o przyporządkowywanie konkretnych sytuacji istotnych z punktu widzenia prawa do systemu rzymskiego. Plaut często bowiem

' W Noctes Atticae $(1,24,3)$ Aulus Gellius zapisal nagrobny epigramat Plauta: Postquam est mortem aptus Plautus, Comoedia luget, /Scaena est deserta $[a c]$ dein Risus, Ludus locusque, / Et numeri innumeri simul omnes conlacrimarunt. 
przekłada po prostu tekst grecki na łacinę. Główne wątki komediowe pozostają niezmienione ${ }^{\star}$. Łatwo zatem wpaść w pułapkę automatycznego odczytywania sztuki modo romano. Tymczasem, jak wspomina sam Plautus, comoedia graecissat ${ }^{4}$. Wydaje się, że uważna lektura doprowadzić może do interesujących wniosków odnośnie do prawa rzymskiego, jak również norm greckich, najczęściej attyckich.

Plaut dostarcza nam bardzo wielu przykładów zwaśnionych małżeństw zbliżających się niebezpiecznie ku rozwodowi. W swojej monografii dotyczącej prawa w komediach Plauta Emilio Costa napisal: É il divorzio infatti, già in questo tempo, non la morte d' uno dei coniugi, il mezzo più consueto per cui il matrimonio si scioglie ${ }^{10}$. Trudno jest stwierdzić, czy rozwód był instytucją powszechnie stosowaną w Rzymie na przełomie III i II wieku p.n.e. Wszystko wskazuje na to, że już ustawy Romulusa zezwalały na dokonanie repudium przez męża w określonych okolicznościach". Przepis dotyczący rozwodów znajdował się także w Ustawie XII Tablic. Ustanawiał on treść formuły rozwodowej (res tuas tibi habeto), oraz nakazywał odebranie odprawianej żonie kluczy: Illam suam res sibi habere iussit ex XII tabulis claves ademit exegit ${ }^{12}$.

Poruszenie, jakie wywołało w społeczeństwie repudium dokonane w roku 230 p.n.e. przez Spuriusa Carviliusa Rugę ze względu na bezpłodność jego małżonki ${ }^{13}$, zdaje się jednak wskazywać na fakt, iż rozwody nie były wówczas na porządku dziennym, jak twierdzi Costa. Rzymianie znali natomiast doskonale formułę rozwodową, bo przecież Ustawy XII Tablic uczyli się na pamięć.

× Por. G. Przychockı, Plautus, Kraków 1925, s. 437-442.

"Plaut., Men. 11.

"' E. CosTA, Il diritto privato romano nelle commedie di Plauto, [przedruk] Roma 1968, s. 177.

"Leges regiae, Rom. 9.

: Tab. 4,3.

${ }^{13}$ Por. A. TARWACKA, Rozwód Canviliusa Rugi - czy naprawde pierwszy?, "CPH" 54.1 (2002), s. 301-308. 
Bohaterami komedii Plauta są często żonaci mężczyźni, którym żony tak dopiekły, że marzą oni o rozwodzie jako o wybawieniu z małżeńskiego piekła. Trzeba jednak wyraźnie zaznaczyć, że w żadnej z komedii nie dochodzi do rozwodu. Palliata miała spełniać rolę nie tylko rozrywkową, ale i, w pewnym sensie, dydaktyczną, a rozbicie małżeństwa zostałoby bez wątpienia poczytane za skandal.

W komedii Menaechmi adoptowany przez kupca Menechmus mieszka w Epidamnum wraz z żoną. Ich małżeństwo to przykład związku, w którym kobieta wiedzie w domu prymat, a mężczyzna egzystuje przy niej jako pantoflarz wykorzystując każdą okazję, aby zrobić jej na złość i wymknąć się spod ciągłej kontroli. Motyw ten był chętnie wykorzystywanym źródłem komizmu w komedii greckiej, powszechnie uważanej za mizoginistyczną: Oto wolny Ateńczyk, korzystajacy na agorze z pelni praw obywatelskich demota, fra-

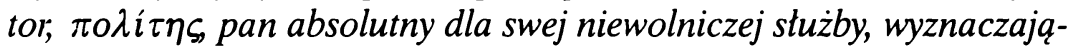
cy „tygodniówkę" dorastającemu synowi, po przekroczeniu progu domu staje się natychmiast, jeśli wierzyć biadaniom komediowych pantoflarzy, niewolnikiem swojej żony ${ }^{14}$.

$\mathrm{Na}$ jakich podstawach prawnych opiera się małżeństwo Menechma? Skąd taka zależność od żony? Plautus wspomina w prologu, że to przybany ojciec Menechma, ów kupiec z Epidamnos, dał mu posażną żonę: eique uxorem dotatam dedit ${ }^{15}$. Według prawa rzymskiego mąż nabywał prawo własności posagu wniesionego przez żonę. Mógł nim dowolnie rozporządzać. W razie rozwodu był jednak zobowiązany zwrócić posag, a żonie przysługiwała już za czasów Plauta pretorska skarga dobrej wiary actio rei uxoriae ${ }^{16}$. Takie rozwiązanie mogło stanowić w rękach kobiety skuteczną broń. Należy jednak dodać, że - gdyby rozwód nastąpił z jej winy - mąż mógł zatrzy-

${ }^{14}$ M. BOROWSKA, OIKEIA ПPAГMATA. Z dziejów dramatis personae rodzinnej komedii greckiej nastepców Arystofanesa, Warszawa 1995, s. 45.

"Plaut., Men., 61.

"Por. A. Söllner, Zur Vorgeschichte und Funktion der 'actio rei uxoriae', Köln-Wien 1969, s. 84-87. 
mać część posagu w ramach tzw. prawa retencji. Prawo attyckie również przyznawało mężowi własność posagu ( $\pi \varrho o i \xi)$, ale, w razie rozwodu, wracał on do rodziny żony ${ }^{17}$.

Wątek finansowej zależności mężczyzny od posażnej żony często pojawia się u Plauta. Demenetus w Asinarii stwierdza wprost: $A r-$ gentum accepi, dote inperium vendidi ${ }^{18}$. Posażna żona pojawia się też w komediach greckich: o sprzedaniu swej wolności za posag mówią bohaterowie komedii Menandra ${ }^{19}$.

W świadomości Rzymian zbyt duży posag wniesiony przez kobietę skłaniał ją potem do stawiania mężowi wygórowanych żądań i do roszczenia sobie prawa do współdecydowania o sprawach finansowych rodziny. W literaturze często pojawiają się rady przestrzegające przed braniem posażnej żony i opinie wypominające kobietom zbytek $^{20}$.

Mimo że Menechmus odziedziczył po przybranym ojcu spory majątek $^{21}$, żona próbuje przejąć kontrolę nad jego życiem. Zatruwa mu je do tego stopnia, że nazywa on ją odźwiernym: Nam quotiens foras ire volo, me retines, revocas, rogitas/ Quo ego eam, quam rem agam, quid negoti geram, / Quid petam, quid feram, quid foris egerim./ Portitorem domum duxi, ita omnem mihi/ Rem necesse eloqui est, quidquid egi atque ago ${ }^{22}$.

Kiedy żona dowiaduje się, że Menechmus wykradł jej suknię, wyrzuca go $\mathrm{z}$ domu i nakazuje wrócić jedynie $\mathrm{z}$ ową palla. O takim wyrzuceniu $z$ domu mówi się excludere foras ${ }^{23}$. Może to wskazywać na fakt, że dom małżonków był częścią posagu i stanowił tzw. aedes

"Por. C. ReInSBERG, Obyczaje seksualne starożytnych Greków, Gdynia 1998, s. 41-43.

${ }^{1 \times}$ Plaut., Asin. 87.

${ }^{14}$ Menander, Sąd polubowny 21-23, Naszyjnik, fr. 333.

"Por. B.M. LelewSKA, Żona posażna $w$ komediach Plauta, «Meander» 53.1 (1998), s. 16-18.

"Plaut., Men. 66: Illi divitiae «ita" evenerunt maxumae.

"Plaut., Men. 114-118.

$\therefore$ Plaut., Men. 668: Male mihi uxor sese fecisse censet, quom exclusit foras. 
dotales. Chociaż w skład posagu najczęściej wchodziły pieniądze, często mówi się też właśnie o nieruchomościach, niewolnikach ${ }^{24}$.

Wygnany z domu Menechmus nie znajduje miejsca także u hetery Erotium. Zdesperowany postanawia poprosić o radę przyjaciól: Ibo et consulam hanc rem amicos, quid faciendum censeant $t^{25}$. Norma prawna faktycznie nakazywała mężowi konsultować poważne decyzje $\mathrm{z}$ przyjaciółmi. Valerius Maximus podaje, że w roku 307/306 p.n.e. z senatu usunięto Luciusa Anniusa, który przeprowadzil rozwód bez konsultacji z przyjaciółmi, mimo że pojął swą żonę jako dziewicę, co potwierdzało jej dobre imię: Horum severitatem M. Valerius Maximus et C. Iunius Brutus Bubulcus censores consimili genere animadversionibus imitati sunt: L. enim Annium senatu moverunt, quod quam virginem in matrimonium duxerat repudiasset nullo amicorum consilio adhibito ${ }^{26}$. Trudno jednak stwierdzić, czy Menechmus nosi się tu rzeczywiście z podjęciem jakiejś decyzji. Być może marzy mu się rozwód.

Małżeństwo Menechma jest dla niego źródłem samych kłopotów, istotnym ograniczeniem wolności. Żona szpieguje go na każdym kroku. Scena druga aktu pierwszego komedii rozpoczyna się monologiem Menechma, w którym grozi on żonie rozwodem, jeśli nie zmieni ona swojego postępowania. Mąż mówi stojąc pod drzwiami domu, żony nie widzimy w ogóle. Dlaczego tak się dzieje? Otóż w teatrze greckim kobiety dobrze urodzone bardzo rzadko pojawiały się na scenie ${ }^{27}$. W życiu codziennym nie pojawiały się one zbyt często na ulicy, a komediopisarze musieli przestrzegać zasad obowiązujących w życiu. Dlatego uciekali sie do różnych podstępów. Kobiety często odzywały się $\mathrm{z}$ wnętrza domu, pojawiały się przed widzami wtedy, gdy odbywało się jakieś święto, w którym mogły uczestniczyć.

\footnotetext{
${ }^{2+}$ Por. B.M. LelewSKA, op. cit., s. 18-19.

$\therefore$ Plaut., Men. 700.

"Val. Max., Mem. 2,9,2.

${ }^{\prime 7}$ M. BOROWSKA, op. cit., s. 53-58.
} 
Obyczaje rzymskie nie były tak surowe, kobiety cieszyły się znacznie większą swobodą. Żona prawdopodobnie musiała mieć jednak zgodę męża na opuszczanie domu, w przeciwnym razie groził jej rozwód. W komedii Mercator niewolnica Syra mówi: Ecastor lege dura vivont mulieres/ multoque iniquiore miserae quam viri./ nam si vir scortum duxit clam uxorem suam, / id si rescivit uxor, inpunest viro;/uxor virum si clam domo egressa est foras, / viro fit causa, exigitur matrumonio./ utinam lex esset eadem quae uxori est viro;/ nam uxor contenta est, quae bona est, uno viro:/ qui minus vir una uxore contentus siet?/ ecastor faxim, si itidem plectantur viri,/ si quis clam uxorem duxerit scortum suam, / ut illae exiguntur quae in se culpam commerent, / plures viri sint vidui quam nunc mulieres ${ }^{28}$.

Zgodnie $z$ jej słowami, jeżeli żona przyłapie męża na cudzołóstwie, nie może nic zrobić, jest on bezkarny. Kiedy jednak ona potajemnie wyjdzie $z$ domu, staje się to podstawą rozwodu. Gdyby to żony miały prawo dokonywać repudium w przypadku zdrady męża, więcej by było rozwodników niż teraz rozwódek. Należy zwrócić uwagę na to, że monolog ten pokrywał się zapewne $\mathrm{z}$ analogicznym w komedii Filemona będącej pierwowzorem komedii Mercator. Przypuszczenie potwierdza analiza fragmentów Eurypidesa przeprowadzona poniżej. Można jednak przypuszczać, że zakazywanie kobietom opuszczania domu bez wiedzy i zgody męża dotyczyło również współczesnych Plautowi Rzymianek.

Przyczyną rozwodu może być zatem potajemne wyjście żony $z$ domu. Nacisk położony jest właśnie na słowo clam, ponieważ kobieta mogła zgodnie $z$ prawem opuszczać dom mężowski. Miała taką możliwość na przykład, gdy nie chciała wejść pod władzę męża przez usus, co zapewniała jej Ustawa XII Tablic: lege XII tab. cautum est, ut si qua nollet eo modo (sc. usu) in manum mariti convenire, ea quotannis trinoctio abesset atque eo modo cuiusque anni [usum] interrumperet ${ }^{29}$. Na pewno jednak mąż musiał wiedzieć

\footnotetext{
¿* Plaut., Merc. 817-828.

:Tab. 6,5.
} 
o wyjściu kobiety. Plutarch opisywał, jak to Publiusz Semproniusz odprawił żonę, którą przyłapał poza domem na oglądaniu igrzysk pogrzebowych ${ }^{30}$. A zatem taki zakaz dla kobiet na pewno istniał. W Braciach matronę widzimy na scenie dopiero wtedy, kiedy - zdesperowana - postanawia przyłapać męża na gorącym uczynku.

Friedrich Leo ${ }^{31}$ wskazuje na dodatkowy, niezwykle interesujący aspekt monologu Syry. Otóż ten fragment Plautowej komedii Mercator wykazuje duże podobieństwo do fragmentów tragedii Eurypidesa. Wiadomo, że sam Plaut czerpał z greckiej komedii średniej i nowej, a ta znowu - właśnie z Eurypidesa. Skoro - tak jak w przypadku komedii Mercator - pierwowzór grecki, czyli "E mona, nie zachował się, warto poszukać podobieństw z Eurypidesem. Wo es sich um menschliche Verhältnisse handelt, die das allgemeine Empjinden berühren, unterscheidet sich die Komödie wenig von Euripides; wo speciell auf die komische Handlung zugeschpitzte Fälle allgemein behandelt werden, tritt natürlich der komische Charakter des Gedankens deutlicher zu Tage ${ }^{32}$.

W Medei tytułowa bohaterka skarży się, że kobieta jest zależna od swojego małżonka, którego najpierw musi kupić (za posag), a potem znosić przez całe życie, nawet jeśli okaże się lajdakiem. Jest także skazana na pozostawanie w domu, podczas gdy on może podróżować, walczyć. Mówi:

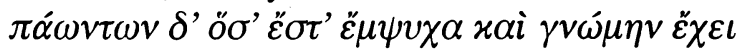

$\gamma v v \alpha \tilde{\imath} x \varepsilon \varsigma \dot{\varepsilon} \sigma \mu \varepsilon v \dot{\alpha} \vartheta \lambda \iota \omega \tau \alpha \tau o v \phi v \tau o ́ v$.

$\grave{\alpha} \varsigma \pi \varrho \tilde{\omega} \tau \alpha \mu \dot{\varepsilon} v \delta \varepsilon \tilde{\imath} \chi \varrho \eta \mu \alpha \dot{\tau} \sigma v \dot{v} \pi \varepsilon \varrho \beta o \lambda \tilde{\eta}$

$\pi o ́ \sigma \iota v \pi \varrho i \alpha \sigma \vartheta \alpha \iota, \delta \varepsilon \sigma \pi o ́ \tau \eta v \tau \varepsilon \sigma \omega ́ \mu \alpha \tau o \zeta$

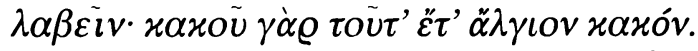

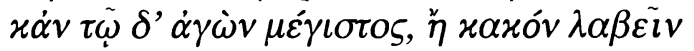

$\ddot{\eta} \chi \varrho \eta \sigma \tau \grave{o} v \cdot o \dot{v} \gamma \dot{\alpha} \varrho \varepsilon \dot{u} x \lambda \varepsilon \varepsilon \dot{\varepsilon} \zeta \dot{\alpha} \pi \alpha \lambda \lambda \alpha \gamma \alpha i$

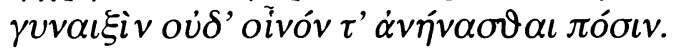

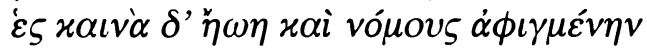

\footnotetext{
30) Plut., Quaest. Rom. 14.

${ }^{31}$ F. LEO, Plautinische Forschungen, Berlin 1895, s. 106-109.

${ }^{32}$ F. LEO, op. cit., s. 106.
} 


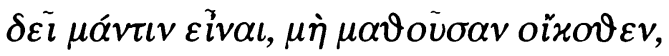

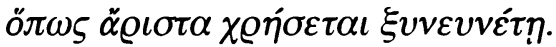

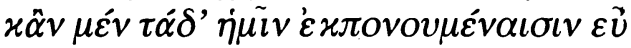

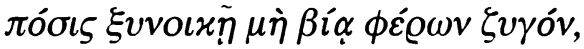
$\zeta \eta \lambda \omega \tau \grave{c} \zeta \alpha i \omega v \cdot \varepsilon i \quad \delta \dot{\varepsilon} \mu \dot{\eta}, \alpha v \varepsilon \dot{\varepsilon} v \chi \varrho \varepsilon \dot{\omega} v$.

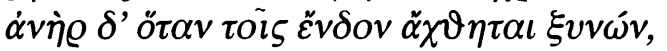

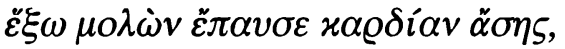

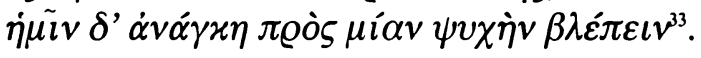

Zdaniem rozgoryczonej Medei, ogromną niesprawiedliwością jest to, że kobieta nie ma prawa wyjść $\mathrm{z}$ domu, a mąż, kiedy zmęczą go sprawy rodzinne, zawsze może spotkać się z przyjaciółmi. Żona nie ma nawet przy sobie krewnych, ponieważ mąż zabiera ją $\mathrm{z}$ domu rodzinnego i wprowadza do swojego.

Bardzo podobną skargę wygłasza Klitajmestra w Elektrze:

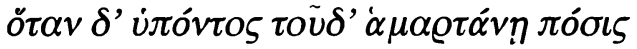

$\tau \ddot{\alpha} v \delta o v \pi \alpha \varrho \omega \sigma \alpha \varsigma \lambda \varepsilon \dot{\varepsilon} \tau \varrho \alpha, \mu l \mu \varepsilon \tilde{\varepsilon} \sigma \vartheta \alpha \iota \vartheta \varepsilon \dot{\lambda} \lambda \varepsilon$

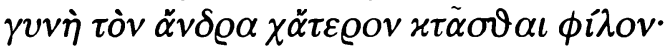

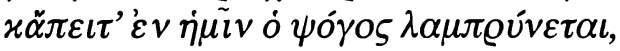

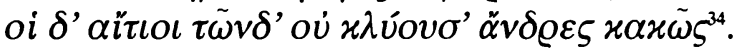

Zdaniem Leo, monolog Syry z komedii Mercator jest dokładnym odzwiercierdleniem skarg kobiet u Eurypidesa: Es ist, in die Lebensverhältnisse der Komödie umgesetzt, genau die euripideische Klage ${ }^{35}$.

${ }^{3}$ Eur., Med. 230-247: Ze wszystkich stworzen żywych i rozumnych/ Kobiety, my, to najnędzniejsze z istot./ Bo wpierw musimy za ciężkie pieniqdze/ Kupić matżonka, pana swego ciatal Brać. Od tej klęski czy jest gorsza klęska?/ Wtedy najcięższa próba czy się wzięto/ Dobrego, czy nie/ Rozstanie niestawa/ Jest dla kobiety, rzuçić go nie mozna./ Idac pod obce zwyczaje i prawa/ Trzeba być wieszczka, nie poznawszy $w$ domu, / Jak tu traktować towarzysza toża./ Jeżeli dobre da nasz trud owocel - Maż żyje z nami nie jakby pod jarzmem -/ To szczęście w życiu - gdy nie, trzeba umrzeć!l Idzie $z$ domu, pozbywa się przesytu sercal (Czy do przyjaciót idąc, czy rówieśnych),/ A nam - na jedna trzeba mieć wzgląd duszę (przel. J. LANOWSKI).

${ }^{34}$ Eur., Electr. 1036-1040: A kiedy tak jest i kiedy maż blądzi/ Wzgardziwszy tożem malżeńskim, kobieta/ Chce naśladować go i wziąc kochanka./ Potem zaś - nasza wina kluje w oczy, / A sprawca winy, mąz, slawy nie traci (przel. J. LANOwSKI).

${ }^{35}$ F. LEO, op. cit., s. 107.

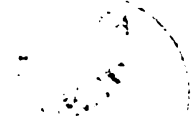


Należy jednak podkreślić, że w żadnym z cytowanych fragmentów Eurypidesa nie ma mowy o rozwodzie. Leo nie bierze pod uwagę prawniczego aspektu tych tekstów. Jak zauważa Yaron: We see that the act disapproved of in Rome 'clam domo egredi' is, at least prima

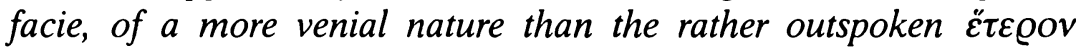

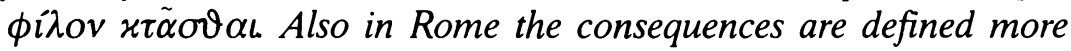

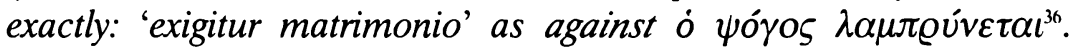
U Eurypidesa mówi się jedynie o winie żony, a nie o konsekwencjach jej postępowania. Nie ma zatem podstaw, aby uważać, że to, co mówi Syra, nie ma odniesienia do realiów rzymskich. Potwierdzić to może fakt, że Plaut posługuje się językiem prawniczym, doskonale zrozumiałym dla Rzymian. Taka aluzja musiała mieć zatem swoje odbicie w obowiązującym prawie.

Monolog Menechma z komedii Menaechmi, w którym grozi on żonie rozwodem, jest bardzo interesujący z punktu widzenia prawnego. Bohater opisuje siebie jako dobrego męża, który wypełnia swoje małżeńskie obowiązki: zapewnia żonie niewolnice, stroje, wełnę, złoto. Ona tymczasem zachowuje się niewłaściwie pragnąc się za wszelką cenę dowiedzieć, co on ma zamiar robić po wyjściu $\mathrm{z}$ domu, z kim się spotyka. Zbytnia dociekliwość uważana była za wadę kobiety. Nawet ojciec zarzuca jej w dalszej części sztuki: quotiens monstravi tibi, viro ut morem geras, / Quid ille faciat ne id observes, quo eat, quid rerum gerat ? $^{37}$.

Dość nietypowe wydają sie słowa, jakich używa Menechmus zapowiadając dokonanie repudium: Praeterhac si mihi tale post hunc diem faxis, faxo foras vidua visas patrem ${ }^{38}$. Nie wypowiada żadnych utartych formuł, stwierdza tylko, że zobaczy ona ojca jako vidua, co oznacza tu nie wdowę, ale rozwódkę. Termin vidua w tym właśnie znaczeniu pojawia się w literaturze dość często ${ }^{30}$. Apulejusz w swojej Apologii

\footnotetext{
${ }^{36}$ R. YARON, Minutiae on Roman Divorce, «TR» 28 (1960), s. 8.

"Plaut., Men. 787-788.

${ }^{* *}$ Plaut., Men. 112-113.

${ }^{34}$ Por. Tac., Ann. 14,64,2.
} 
podaje przyczynę podobnego traktowania rozwódek i wdów. Otóż dla Rzymianina mającego zamiar się ożenić podstawowym atutem wybranki było jej dziewictwo. Apulejusz przekonuje, że właśnie dlatego rozwódka niczym się nie różni od wdowy, kiedy chce powtórnie wyjść za mąż, iż obie nie mogą się już poszczycić dziewictwem. A ono jest najbardziej przez męża pożądaną częścią posagu. W razie bowiem zerwania małżeństwa, będzie musiał zwrócić wszystko inne, a dziewictwo żony pozostanie na zawsze jego własnościąat.

Żona Menechma także nie jest zachwycona swoim małżeństwem. Kiedy nabiera pewności, że małżonek wyniósł $\mathrm{z}$ domu jej suknię i podarowal ją heterze, postanawia wezwać ojca. Prosi go o zabranie jej z domu mężowskiego: verum vivere hic non possum, neque durare ullo modo. proin tu me hinc abducas. ... ludibrio, pater, habeor ... ab illo, quoi me mandavisti, meo viro ${ }^{41}$. Prawo rzymskie w czasach Plauta raczej nie zezwalało kobiecie na dokonanie rozwodu. Trudno ustalić, czy mógł go w jej imieniu przeprowadzić $p a-$ ter familias. Jest to raczej wątpliwe w przypadku małżeństw, które łaczyły się z conventio in manum mariti. W prawie attyckim możliwe było tymczasem rozwiązanie małżeństwa tak przez męża, jak i przez żonę, a także jej ojca ${ }^{42}$. Przyczyną, dla której żona mogła wy-

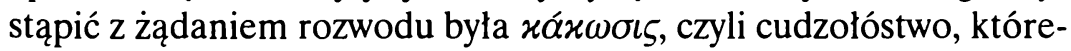
go mąż dopuścił się we wspólnym domu małżonków ${ }^{\star 3}$. Menechmus spotyka sie z heterą jedynie poza domem, o czym mówi: Hodie ducam scortum atque aliquo ad cenam condicam foras ${ }^{44}$. Dlatego jego

"Apul., Apol. 92; por: Val. Max. Mem. 2,9,2.

"Plaut., Men., w. 781-783, por. Plaut., Merc., w. 787-788: Syra, i, rogato meum patrem verbis meis, ut veniat ad me iam simul tecum.

'2 Por. J. Roy, Polis and oikos in Classical Athens, "Greece \& Rome» 46.1/IV (1999), s. 9.

${ }^{43}$ Por. H. KUPISZEWSKI, Dyskolos Menandra i jego znaczenie dla prawa greckiego i rzymskiego, «Eos» 52.1 (1962), s. 50; TENŻE, Menanders 'Dyskolos' und seine Bedeutung für die Kenntnis des griechischen und römischen Familienrechts, [w:] Menanders 'Dyscolos' als Zeugnis seiner Epoche, Berlin 1965, s. 118.

${ }^{\star}$ Plaut., Men. 124. 
żona wzywa ojca, aby to on podjął inicjatywę rozwodową (proin tu me hinc abducas).

Scenę tę badacze starają się też interpretować na gruncie prawa rzymskiego. Watson ${ }^{45}$ wysuwa hipotezę, że Plautus, dokonując przekładu komedii greckiej, usunął $z$ niej elementy prawnie relewantne, a żona Menechma wzywa ojca jedynie po to, aby ten przywołał zięcia do porządku. W tym wypadku małżeństwo Menechma traktowane jest jako związek sine manu. Watson argumentuje, że postacie nie wspominają w tej scenie o rozwodzie. Wydaje się jednak, że zdecydowanym odwołaniem do rozwodu jest tu czasownik abducere, który stanowić może przeciwieństwo deducere w zwrocie deductio in domum mariti określającym wprowadzenie do domu mężowskiego nowo poślubionej małźnki.

Dalej przywołuje Watson inną możliwą interpretację, zgodnie z którą prawo rzymskie wymagało obecności ojca żony dla dokonania przez nią rozwodu. Zakłada się tu więc, że kobieta mogła wystąpić z żądaniem rozwodu, co w czasach Plauta wydaje się nader wątpliwe. $Z$ drugiej strony, istnieje także możliwość, że małżeństwo sine manu mogło być rozwiązane przez pater familias żony. Watson wydaje w tej sprawie wyrok non liquet.

Treggiari $^{46}$ jest zdania, że publiczność Plauta utożsamiała sytuację greckiej $\gamma v v \grave{\eta} \gamma \alpha \mu \varepsilon \tau \eta ́$ z położeniem Rzymianki, która nie weszła pod manus męża. Zastrzega jednak, że nie uznaje komedii za wiarygodne źródło wiedzy o prawie.

Trudno jest tu o kategoryczne rozstrzygnięcie. Wydaje się, że Plautus tworzył komediowe małżenstwa na podstawie greckich pierwowzorów i - chociaż często odwoływał się do rzymskich instytucji prawnych - to sama konstrukcja związku pozostaje najczęściej grecka. Publiczność musiała jednak rozumieć, co się dzieje na scenie. Przekonująco brzmi tu zatem teoria, że prawo

${ }^{15}$ A. Watson, The Law of Persons in the Later Roman Republic, Oxford 1967, s. 51.

th S. TReggiari, Roman Marriage. Iusti coniuges from the time of Cicero to the Tome of Ulpian, Oxford 1991, s. 443. 
rzymskie dopuszczało możliwość zerwania małżeństwa nie połączonego z conventio in manum decyzją pater familias kobiety.

W Stichusie natomiast ojciec chce zerwać małżeństwa swoich córek, ponieważ zięciowie bardzo długo nie wracają z podróży. Córki nie chcą się na to zgodzić, ale - gdyby nie zdołały przekonać ojca siłą argumentów - musiałyby się podporządkować jego władzy: pati nos oportet, quod ille faciat, quoius potestas plus potest ${ }^{47}$. Należy jednak podkreślić, że ojciec nie dąży tu do przeprowadzenia rozwodów córek, ale do nakłonienia ich do ponownych małżeństw, a tym samym do uznania ich mężów - nieobecnych od trzech lat - za zmarłych.

W komedii Amphitruo sytuacja sceniczna jest nad wyraz skomplikowana, ponieważ z jednej strony bohater tytułowy podejrzewa żonę o zdradę, $\mathrm{z}$ drugiej natomiast ona ma do niego pretensje o te oskarżenia. Cały ten bałagan wywołany został przez Jowisza, który pod nieobecność Amfitriona zastępował go u boku jego żony przybierając jego postać. Merkury przewiduje problemy, które powstaną, kiedy zjawi się prawdziwy mąż: Nam Amphitruo actutum uxori turbas conciet, atque insimulabit eam probri ${ }^{48}$. I rzeczywiście, natychmaist zarzuca on żonie dopuszczenie się cudzołóstwa: Nunc domum ibo atque ex uxore mea hanc rem pergam exquirere, quis fuerit quem propter corpus suom stupri conpleverit $t^{49}$. Alkmena znajduje się $\mathrm{w}$ bardzo trudnym położeniu, ponieważ na szwank wystawiono jej cześć. Dlatego decyduje się odejść od męża: valeas, tibi habeas res tuas, reddas meas ${ }^{50}$. Używa zatem tradycyjnej formuły rozwodowej. Watson uważa, że to ona przeprowadza tu rozwód, jako że jej małżeństwo z Amfitrionem jest sine manu: In the Amphitruo at 928 the wife, Alcumena, utters the traditional

t7 Plaut., Stich. 68-69.

** Plaut., Amph. 476-477.

ty Plaut., Amph. 1015-1016; stuprum oznacza wlaściwie stosunek z kobietą niezamężną: panną lub wdową, ale tego technicznego znaczenia wyraz ten nabral dopiero w ustawach małżeńskich Augusta - tu oznacza, jak adulterium, cudzołóstwo.

so) Plaut., Amph. 928. 
words of divorce, and so this is a marriage sine manu. It is really inconceivable that Plautus is making a joke here in that these words could properly be uttered only by a man. That would be against the whole fun of the situation, for which it is essential that Alcumena should behave seriously and rationally in the circumstances as she sees them ${ }^{51}$. Można mieć jednak wątpliwości co do tego, czy to Alkmena dokonuje tu repudium. Należy najpierw przyjrzeć się scenie, w której sytuacja ta ma miejsce. Otóż Jowisz pod postacią Amfitriona usiłuje cofnąć mężowskie oskarżenia twierdząc, że zostały one wypowiedziane tylko dla żartu: equidem ioco illa dixeram dudum tibi, ridiculi causa ${ }^{52}$. Alkmena nie chce jednak przyjąć takiego usprawiedliwienia, ponieważ czuje się pokrzywdzona i znieważona: ab inpudicis dictis avorti volo ${ }^{53}$. Chce wyjść $\mathrm{z}$ honorem $\mathrm{z}$ całej sytuacji i dlatego wybiera najbardziej podniosłą formułę, jaka jej przychodzi do głowy. Tyle tylko, że nie wypowiada jej dokładnie, a jakby na odwrót: tibi habeas res tuas, reddas meas. To mąż ma sobie zatrzymać swoje rzeczy, a oddać żonie jej własność. Domu nie opuści on, ale ona. Plaut dokonał zatem komicznego odwrócenia ról: żona wypowiada za męża słowa, które przypieczętowują rozwód, lecz jak gdyby wspak. Wychodzi to tak, jakby to on dokonał repudium. Wszystko odbyło się więc zgodnie z prawem. Widz, który zna dobrze formułę prawną, bawi się świetnie, bo rozumie doskonale komizm sytuacji, a przy tym podoba mu się mistrzostwo dokonanej sztuczki słownej.

Wydaje się, że ilekroć u Plauta żona występuje $z$ inicjatywą rozwodową, ma to na celu efekt komiczny, a nie jest odzwierciedleniem faktycznej sytuacji prawnej ${ }^{54}$. Często chodzi tu o pokazanie, jak bardzo mąż boi się żony, która wniosła posag i faktycznie rządzi całym majątkiem.

\footnotetext{
s' A. WATSON, op. cit., s. 52.

s Plaut., Amph. 916-917.

${ }^{53}$ Plaut., Amph. 927.

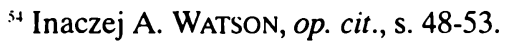


W komedii Miles Gloriosus niewolnik Palestrio knuje przeciwko Pyrgopolinicesowi intrygę służącą połączeniu dwojga zakochanych: Filokomazjum i Pleusiklesa. Przekonuje on żołnierza, że żona jego sąsiada jest w nim zakochana. Sąsiad jednak nie ma żony, w jej rolę wciela się hetera, Agroteleutium. Pyrgopolinicesa, aby nie bał się wchodzić do domu innego mężczyzny, sprytny niewolnik chce przekonać o tym, że sąsiad się rozwiódł, a dom należy do byłej żony jako część posagu. Tak tłumaczy heterze jej rolę: omne ordine. nisi modo unam hoc: hasce esse aedis dicas dotalis tuas, hinc senem aps te abisse, postquam feceris divortium: ne ille mox vereatur introire in alienam domum $^{55}$. Z tekstu mogłoby wynikać, że to żona doprowadziła do rozwodu. W dalszej części komedii przeczytać możemy rozmowę żołnierza ze służącą Agroteleutium: PYRGOPOLINICES: egon ad illam eam quae nupta sit? vir eius me deprehendat. MILPHIDIPPA: quin tua caussa exegit virum ab se. PY: qui id facere potuit? MI: [quia] aedes dotalis huiiu' sunt. PY: itane? MI: ita pol. PY: iube domum ire ${ }^{56}$. Ten fragment wprowadza nieco zamieszania. Otóż nie możemy być już wcale pewni, że w ogóle chodzi o rozwód, ponieważ Pyrgopolinices wyraźnie mówi o kobiecie zamężnej. Wiadomo, że wyrzuciła męża $z$ domu. Tekst nie daje nam także żadnych podstaw do tego, żeby sądzić, iż chodzi o rozwód dokonany przez żonę. Przede wszystkim w rzeczywistości żadna żona nie istnieje, a cała intryga ma na celu wprowadzenie w błąd żołnierza, który nie grzeszy przesadną inteligencją. Dlatego wydaje się, że w pierwszym z zacytowanych fragmentów wyraz divortium mógł zostać użyty w znaczeniu nietechnicznym.

O tym, że Plaut często bawi się utartymi formułami prawnymi i nie stosuje ich wyłącznie w ich znaczeniu technicznym, może przekonać fragment komedii Trinummus: Apage te, Amor; tuas res tibi habeto $^{57}$. Znanych nam słów res tuas tibi habeto używa Lysiteles w swoim monologu skierowanym do boga miłości, Amora. Mło-

\footnotetext{
${ }^{55}$ Plaut., Mil. Glor. 1164-1167.

${ }^{56}$ Plaut., Mil. Glor. 1276-1278.

${ }^{57}$ Plaut., Trin. 266.
} 
dzieniec chce się go wyrzec sądząc, że przynosi on ludziom więcej szkody niż pożytku i że jest on niebezpieczny: Nam qui in amorem praecipitavit, peius perit quasi saxo saliat ${ }^{58}$. Ostatecznie ucieka się do formuły rozwodowej, aby pokazać swoją determinację i na zawsze uwolnić się od natrętnego boga.

W komedii Casina czytamy natomiast: MYRRHINA: insipiens, semper tu huic verbo vitato abs tuo viro. CLEUSTRATA: quoi verbo? MY: ei foras, mulier ${ }^{59}$. Wydaje się, że jest to po prostu zdanie, które w brutalny sposób informuje żonę o tym, iż mąż podjął decyzję o rozwodzie. Byłoby więc mniej wyrafinowaną odmianą res tuas tibi habeto.

Podejrzeń o cudzołóstwo u Plauta nie brakuje. Wiemy już, że żona nie mogła w żaden sposób ukarać męża zdrajcy, a przynajmniej nie dawało jej takiej możliwości prawo. Odegrać się mogła tylko wykorzystując swoją pozycję w domu, szczególnie jeśli dysponowała (znowu tylko faktycznie) posagiem. Co innego mąż ... W omawianym już wcześniej Amphitruo Alkmeon obawia się, że jego żona popełniła adulterium i wściekły wbiega do domu krzycząc: ubi quemquem hominem aspexero, sive ancillam, sive servom, si uxorem, si adulterum, si patrem, si avom videbo, eum obtruncabo in aedibus ${ }^{(1)}$. W Siostrach czytamy: ni illic hodie forte fortuna hic foret, miles Mnesilochum cum uxore opprimeret sua atque optruncaret moechum manufestarium ${ }^{\prime \prime}$. Chodzi tu zatem o sytuację, kiedy mąż zabija kochanka żony przyłapawszy ich na gorącym uczynku.

W Atenach dozwolona samopomoc obejmowała przypadek złapania złodzieja lub $\mu$ oí $\chi \varsigma^{62}$. Pan domu mógł zabić kochanka swojej żony, córki, matki lub siostry i nie groziła mu za to, jak w przypadku zabójstwa, kara wygnania. Prawo rzymskie również nie karało mężów za zabicie cudzołożnika przyłapanego z żoną.

\footnotetext{
${ }^{58}$ Plaut., Trin. 265a-265b.

${ }^{54}$ Plaut., Cas. 210-212.

"Plaut., Amph. 1048-1050.

${ }^{n 1}$ Plaut., Bacch. 917-918.

62 Por. M.R. Christ, Legal Self-Help in Defence of the oixos, «American Journal of Philology» 119.4 (1998), s. 522.
} 
W komedii Bacchidae pojawia się jednak również wzmianka o zabiciu cudzołożnicy: Nihil est lucri quod me hodie facere mavelim quam illum cubantem cum illa opprimere, ambo ut necem ${ }^{6.3}$. W prawie ateńskim nie było przepisu zezwalającego mężowi zabić żonę. Mógł on wygnać ją z domu i przeprowadzić rozwód. Prawa Solona zakazywały również kobiecie przyłapanej na cudzołóstwie noszenia jakichkolwiek ozdób i odwiedzania świątyń, czyli pozbawiały ją podstawowych rozrywek dostępnych Atenkom ${ }^{64}$.

Według Dionizjusza z Halikarnasu, w ustawach Romulusa znajdował się przepis zezwalający na ukaranie śmiercią kobiety, która dopuściła się cudzołóstwa albo piła wino:

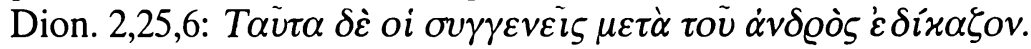

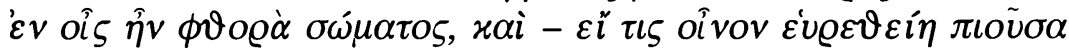

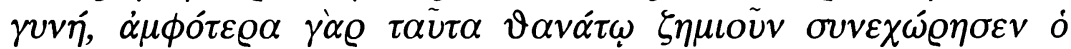

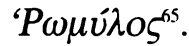

Autor podkreśla jednak wyraźnie, że wyrok wydawał mąż wraz $\mathrm{z}$ krewnymi kognacyjnymi (iudicium domesticum).

Powyższe rozważania pozwalają wysnuć wniosek, że Plaut, odwołując się w swoich komediach do instytucji rozwodu, stał na gruncie prawa rzymskiego. Świadczą o tym przede wszystkim gry słowne bazujące na formule res tuas tibi habeto. Rzymianie, znający przecież Ustawę XII Tablic na pamięć, doceniali żarty z jej przepisów. Wydaje się również, że rozwody stanowiły wtedy element życia codziennego i nie były postrzegane jako skandal obyczajowy. $\mathrm{Z}$ pewością również widzów bawiły dowcipy na temat posażnych żon terroryzujących swych małżonków: mężczyźni mogli śmiać się do woli udając często, że ich ten problem zupełnie nie dotyczy.

\footnotetext{
${ }^{63}$ Plaut. Bacch. 859-860.

(4 Aeschines, Timarch. 183; por. N.A. VRISSimitzis, Love, Sex and Marriage in Ancient Greece, Greece 1997, s. 41-42.

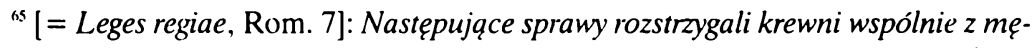
żem: wśród nich byto cudzotóstwo oraz jeśli okazato się, że kobieta pita wino; oba te przestepstwa Romulus zezwolit karać śmiercia.
} 


\section{EI foras mulier, viz. DivorCe in Plautus' Comedies}

\section{Summary}

The Romans treated law as a very important element of everyday life. That is why their literature is so full of allusions to law.

Plautus wrote his comedies for nearly 30 years, between 210 and184 B.C. His plays were based on the Greek Middle and New Comedy. It is not always easy to distinguish the parts where he refers to Roman law from those where he simply translates the original text without making any changes.

In many of Plautus' plays we can find information about divorce, though divorce was never shown on the stage for obvious moral reasons.

In Menaechmi the husband threatens his wife with repudium because he feels a slave in his own house - an ideal wife should - under no circumstances - spy on her husband or even ask him about his affairs. The position of a men in this relationship is rather weak - his wife brought a large dowry and he is simply afraid of what he could lose by ending his marriage. In Mercator Syra, a slave-woman, comments that husbans are allowed to have sexual contacts with other women, whereas their wives can be easily repudiated even if seen outside their houses without a permission. There seems to have been no possibility for a woman to demand divorce in Rome of the III/II century B. C. Plautus uses this fact for comical purposes. In Amphitruo Alcumena speaks the formula of repudium as if backwords: tibi habeas res tuas, reddas meas, making it sound as if it was her husband to repudiate her.

Plautus gives a lot of evidence that divorces were quite common in his times and that the Romans knew perfectly all its legal aspects. 